appeadix, hrings ahont a cure. The nther cases are numerous in which the patieats saffer great distress, in which it is impossible to givc any name to the disease or to offer any explanatinn of the symptoms. It has heen demonstrated that a great many of thess cases are relieved, and, indeed, curcd by ahdomianl section after all medical mensures have fniled.

There is a sometrhat more defiaite form of nbdominal trouble that the anthor imagines may lay claim to the term "intestingl hypochondriasis." Many of the patieats who nre the victims of this coadition are mea, mostly of middle age. Nearly if not all have been the suhjects of chroaic colitis. They are npt to complain of fixed pain nnd teaderness at $n$ spot $\mathrm{a}$ little helow and to the left of the umbilicus. The spot indicated would not he far removed from ths inferior mesenteric ressels and plexus. These patients suffer from troahlesome constipation, from dyspeptic troubles, from sickening pain in the shrionen, and from iadefinite depression. The whole mind is engrossed hy the considention of their howels and ths contemplation of the coacerns of their andomen. There is no douht, from the study of these a ad similar cases, that the sigmoid flexure is a very irritahle pnrt of the alimeatary cansl. It is possible that, in these cases, loag-continaed catarrh has led to a permanent state of irritahility of the muscle forming the bowel wall, to $n$ condition of ahiding spasm, which may well cause pain and the sensatioas of nbstruction. Various distortions of the coloa and sigmoid have heen ohscrved hy the nuthor, and gave rise to chronic constipntion. Cases of idiopathic dilatation of the hollow viscern have heen shown frequently to depend npoa a stricture of their normnl nutlet, though they are often met with where no snch conditinn is present. The term is too freely employed where a ccrtain diagnosis bas not heen established.

The Operative Surgery of the Joints, - In regard to operation on the joints, MARAg (British Mledical Journal, March 5, 1898) says there is an ohvious parallel to he drawn hetwecn the joiats nnd the nhdomen in regard to ths results thnt have followed the introduction of asepsis into surgical practice. It is certain that it is just as safe to npen the knee, or any other joint, as it is to open the ahdomen, and that, as in the casc of the peritoneum, so in that of the synovial memhranes, the nld view that thess structures are in some why inhereatly unsuitahle for nperative treatmeat is erroacous.

As an illustration of the truth $n f$ this statement, he relates the results which he has ohtained in the open treatment nf differeat joints for the various injuries. In operations for loose cartilages in the knee-joint he prefers their removal to suture, and in all of the twelve cases operated npon ths functioal resalt has heen perfect and the recovery afehrile.

Loose bodies in ths Eaee are also favorahly aperated upon, and in two recent cases which he reports extensive manipulation was extremely well horne, with a perfect recovery and complete restoration of function.

Satare of the patella represents a test-operatioa hy the open method in receat or old fractares. The results nhtained appear to show concluaively that this nperation has taken its place nn ths list of recent advauces in practical surgery, and the evidence it affords ns to the tolerance hy the joints of activo interferenca is sufficiently conclnsive.

Ths geaeral safety with which excision nf the joints can now he performed 
is hest illustrated hy the resnlts ohtained in the case of the knee-the largest of the joints-and that in which an operation involves the most extensive wound of the soft parts, and the largest exposare of cancellons hone. Yet when care is taken to select approprinte csaes, primary union after excision of the inee is as certain to take place as it is after ovariotomy or removal of the appendix.

Operation in sncro-ilinc disease the anthor helieves to he as free from danger under ascptic conditious as is operating on the other joints, and he holds that excellent results crn he ohtnined even where the disense, in this purticular region, has advanced to a cousiderahle extent. He iliustrates the results ohtainahle hy the histories of five cases where operation produced gratifying results.

\section{THERAP EUTICS.}

\section{UNDER THE CASRGE OF}

REYNOLD W. WILCOX, M.D, I.T.D.,

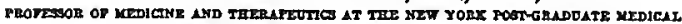

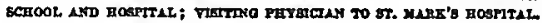

Iocomotor Ataxia Treated with Strychnine Nitrate, $-D R$. EsrrL ALTstas reports a single instance in which, after increasing doses of Fowler's solution, spinal cord stretching, and static electricity had falled, this remedy was used. Strychnine nitrate, 1 ; glycerin, 240 ; water, 240 , was the solution employed, hypodermstically. The initial dose was $\frac{1}{8} \mathrm{gr}$. (10 drops of the above solution), which was incrensed nntil a dose of $t \mathrm{gr}$. was reached; ncxt, heginning with the initial doses, it was increased until $\frac{1}{8} \mathrm{gr}$. was attained. Again, starting with the initial dose it was doubled, and trehled, uatil $\frac{3}{5}$ gr. was taken at a dose. Under this trestment the pains did not return, the msn could walk with the aid of a cane, and his gencral symptoms improved. Strychnine relieves some of the symptoms of the affection, and hy nourishing the starved fibres of the cord prevents further progress of the disease.-The Post-Graduate, 1898, No. 7, p. 585.

Traumatic Tetanus.-MM. A. GHA GFFARD and QuÉsv report asuccesfful instaace of the intracerehral injection of antitoxin. Observation has ghown that while antitetnnic serotherapy is certainly preventive, it is often useless or inadequate when tetanus is well estahlished. Roux and Borrel have explained this as follows: The nerve-cells have not the same affinity for antitoxin as for toxin. Also, tetsnic antitoxin injected into animals remains in the blood, while toxin is extracted and fixed by the nerve-elements. The contra-poison does not come in contact with the poison; the two sahstances, althongh so close, do not meet. The serum is efficacions against the toxin when injected under the skin, hecause the greater portion of it passes into the hlood, hut it is powerless against the poison which has already resched 